\title{
Sealing the Border: US refuses asylum torture survivors
}

\author{
Gerald Gray*
}

Dear Editor,

The Republican Administration has already built The Wall, unknown to the U.S. public. It has done so quietly, administratively, in the large section of the Texas-New Mexico border called the "El Paso Sector." A physical fence covers most of this border. The El Paso legal crossing appears to exist, but in fact does not function. The field director of this sector has been promoted to Assistant Director of the ICE Enforcement Division (Enforcement and Removal) in Washington, DC.

These two facts make it clear the El Paso Sector is an experiment to be implemented on the entire border.

This letter is a summary of the report "Sealing the Border," a 44 page report documenting the current US government's virtual refusal to recognize political asylum for torture survivors, those receiving death threats, and other forms of danger. It also points to a de facto racial and ethnic barrier to all immigrants at the southern border of the U.S. The document was produced this January, 2018, by a coalition of church officials, academic researchers, attorneys, and other professionals in the El Paso
Sector. ${ }^{1}$

Some of the main points of the document at issue:

1. Informally and off the radar, at the border asylum applicants are told such things as that the U.S. no longer accepts political asylum seekers. Here also, families are first separated. Misinformation is deterrence at the border; if a person persists, the next step is detention.

2. If not deterred at the border, virtually all those applying for political asylum or immigration are imprisoned in one of three prisons on the U.S. side of the Sector, where they await the processing of their applications - which in effect never happens. They are held months until they give up their appeals and return to Mexico. They used to be allowed to live in the U.S. awaiting success or failure of their applications

3. Family members are put into separate desert prisons, children divided from parents, couples from each other, and those imprisoned are moved around among the prisons. This way, parents

1 The complete report can be found online at https://www.hopeborder.org/sealing-the-border or https://www.borderlandimmigrationcouncil.org/ sealing-the-border
*) Co-Director, Institute for Redress \& Recovery, Santa Clara University School of Law, Santa Clara, California

Correspondence to: ggraycal@gmail.com 
do not know where children are, and in case an applicant happens to have an attorney, the attorneys cannot readily find clients. Attorneys cannot afford leaving their offices to go hundreds of miles from prison to prison. In effect, this means most of the imprisoned cannot have legal representation even if they can afford it

4. ICE attorneys have been appointed immigration judges. In 2017, according to an ICE report, there were 21,420 persons imprisoned along the border here. Two of the three prisons used are for-profit institutions, and private subcontractors work in the Immigration and Customs Enforcement (ICE) prison. The Border Patrol is permitted to stop anyone for questioning within 100 miles of the border, with the possibility of imprisonment.

5. Should a person get as far as an immigration court hearing, the definition of "torture" has been subverted in political asylum appeals alleging danger. Asylum applicants are asked if they themselves were directly victims of just physical torture, and only this counts; witnessing or knowing of the torture of others, suffering disappearances of family or colleagues or friends-these are not allowed. In short, psychological torture is disallowed, while being forced to watch or otherwise experience torture is a common form of torture.

6. Bail bonds are essentially unavailable because bail prices are raised so high that most imprisoned asylum applicants and immigrants cannot wait for their hearings outside a prison.

7. A variety of other serious issues abound: deportation of asylum seekers and immigrants without notice to their attorneys, inadequate language translation in hearings, extraordinarily high rejections of asylum applications (in the high $90 \%$ area), loss of papers or denial to attorneys of the right to see them, etc. Deportation is high even among prisoners not voluntarily giving up appeals.

8. The separation of children from parents into unknown prison locations is forced disappearance, a form of torture. The separation and imprisonment of all family members is institutional torture. Sealing the border entirely consigns many to torture and summary execution.

\section{References}

Hope Border Institute (2018). Sealing the Border: The criminalization of asylum seekers in the Trump era. Hope Border Institute. 